\title{
A RARE CASE OF COLD AGGLUTININ SYNDROME AS AN EXTRAGLANDULAR MANIFESTATION OF SJÖGREN'S SYNDROME
}

\begin{abstract}
Leonardo Flavio Guerron Olalla ${ }^{1, *}$, Andre Silva Franco ${ }^{1}$, Isabele Parente de Brito Antonelli ${ }^{1}$, Guilherme Guimaraes Moreira Balbi ${ }^{1}$, Karina Fernanda Pucha Anguisaca ${ }^{1}$, Elcio Koodiro Yoshida ${ }^{1}$, Maiana Hamdan Melo Coelho' ${ }^{1}$, Guilherme Henrique Hencklain Fonseca ${ }^{1}$, Sandra Gofinet Pasoto ${ }^{1}$, Samuel Katsuyuki Shinjo ${ }^{1}$, Diogo Souza Domiciano ${ }^{1}$
\end{abstract}

1.Universidade de São Paulo, São Paulo (SP), Brazil.

${ }^{\star}$ Corresponding author: leonlegogo@hotmail.com

\section{BACKGROUND}

Autoimmune hemolytic anemia (AlHA) in Sjögren's syndrome (SS) is uncommon. Usually, it is associated with warm antibodies. Cold agglutinin syndrome (CAS) is a rare autoimmune hemolytic anemia mediated by antibodies that bind to erythrocyte surface at low temperatures, causing agglutination and complement-mediated hemolysis. It can be primary (cold agglutinin disease) or secondary mainly to Mycoplasma pneumoniae pneumonia, Epstein-Barr (EBV) virus infection, or aggressive lymphoma. It is rare occurring in association with autoimmune diseases. We reported here a case of CAS in primary SS.

\section{CASE REPORT}

A 56-year-old woman was admitted with 6-month history of asthenia, pallor, jaundice, dyspnea on moderate exertion and recent episodes of syncope. Laboratory evaluation revealed hemoglobin, $6 \mathrm{~g} / \mathrm{dL}$ (normocytic and normochromic erythrocytes); white blood cell count, 6,960/mm3 (neutrophils 4,350, lymphocytes 2,262); platelet count, 120,000/mm3); erythrocyte sedimentation rate, $104 \mathrm{~mm} / \mathrm{h}$, C-reactive protein, $0.7 \mathrm{mg} / \mathrm{dL}$; normal liver tests; creatinine, $0.79 \mathrm{mg} / \mathrm{dL}$ and normal urine routine. Further evaluation revealed high indirect hyperbilirubinemia ( $2.14 \mathrm{mg} / \mathrm{dL}$ ), high serum lactate dehydrogenase ( $683 \mathrm{UI} / \mathrm{L})$; reticulocytosis $(14,5 \%)$, low serum haptoglobin (1:320), rheumatoid factor (> $450 \mathrm{IU} / \mathrm{mL}$ ) and anti-SSA/Ro (45 IU/mL); anti-SSB/La, anti-dsDNA and anti-Sm were negative. Salivary scintigraphy showed severe hypofunction of glands and labial salivary gland biopsy evidenced focal lymphocytic sialadenitis (focus score 3.3). Thus, primary SS presenting with CAS was diagnosed. Prednisone $1 \mathrm{mg} / \mathrm{kg} / \mathrm{day}$, hydroxychloroquine $5 \mathrm{mg} / \mathrm{kg} /$ day and azathioprine $2 \mathrm{mg} / \mathrm{kg} /$ day were introduced. She also received lubricating eye drops and artificial saliva to control dry symptoms.

\section{CONCLUSION}

There were few cases of AlHA related to SS described in the literature. Here we reported a still more uncommon situation in SS, which is cold agglutinin-mediated AlHA. Cold agglutinin syndrome is a rare condition that, when occurring secondary to overlying disease, is commonly associated to infection or aggressive lymphoproliferative disorder.

\section{KEYWORDS}

Autoimmune hemolytic anemia, Sjögren’s syndrome, Warm antibodies, Cold agglutinin-mediated. 